\section{Drs. Mathai and Hassoun reply}

\section{To the Editor:}

We thank Drs. Koestenberger and Ravekes for their comments ${ }^{1}$. An integral part of validation of a biomarker is the definition of normal (and abnormal) values for the measure. For the tricuspid annular plane systolic excursion (TAPSE), there are few studies that report these data, particularly in adults $2,3,4$. In general, the existing studies are limited by relatively small sizes. The studies done by Koestenberger and Ravekes and Nunez-Gil and colleagues ${ }^{5}$ involve larger populations of children and adolescents and thus provide a useful reference to which values from diseased populations can be compared. In addition, it also remains to be determined whether TAPSE is a sensitive tool for assessing response to therapy in both adults and children; if so, it could be used as an endpoint in clinical trials of therapeutics. Future studies should focus not only on establishing normative ranges of values of TAPSE in large populations of adults, but also on determining the responsiveness of TAPSE in both adults and children.

STEPHEN C. MATHAI, MD, MHS, Johns Hopkins University - Medicine, Division of Pulmonary and Critical Care Medicine; PAUL M.

HASSOUN, MD, Johns Hopkins Asthma and Allergy Center, Baltimore, Maryland, USA. Address correspondence to Dr. Mathai, Johns Hopkins University - Medicine, Division of Pulmonary and Critical Care Medicine, 1830 E. Monument St., Room 516, Baltimore, MD 21205, USA.E-mail: smathai4@jhmi.edu

\section{REFERENCES}

1. Koestenberger M, Ravekes W. Right ventricular function in systemic sclerosis-associated pulmonary arterial hypertension [letter]. J Rheumatol 2013;40:90-1.

2. Innelli P, Esposito R, Olibet M, Nistri S, Galderisi M. The impact of ageing on right ventricular longitudinal function in healthy subjects: A pulsed tissue Doppler study. Eur J Echocardiogr 2009;10:491-8.

3. Germing A, Gotzmann M, Rausse R, Brodherr T, Holt S, Lindstaedt M, et al. Normal values for longitudinal function of the right ventricle in healthy women $>70$ years of age. Eur $\mathrm{J}$ Echocardiogr 2010;11:725-8.

4. Bruhl SR, Chahal M, Khouri SJ. A novel approach to standard techniques in the assessment and quantification of the interventricular systolic relationship. Cardiovasc Ultrasound 2011;9:42.

5. Nunez-Gil IJ, Rubio MD, Carton AJ, Lopez-Romero P, Deiros L, Garcia-Guereta L, et al. Determination of normalized values of the tricuspid annular plane systolic excursion (TAPSE) in 405 Spanish children and adolescents. Rev Esp Cardiol 2011;64:674-80.

J Rheumatol 2013;40:1; doi:10.3899/jrheum.121146 